Article

\title{
Effects of Sulfuric Acid on the Curing Behavior and Bonding Performance of Tannin-Sucrose Adhesive
}

\author{
Zhongyuan Zhao ${ }^{1,2}, *\left(\mathbb{D}\right.$, Yanfeng Miao ${ }^{2}$, Ziqian Yang ${ }^{2}$, Hua Wang ${ }^{2}$, Ruijuan Sang ${ }^{2}$, \\ Yanchun Fu ${ }^{2}$, Caoxing Huang ${ }^{3}$, Zhihui $\mathrm{Wu}^{2}$, Min Zhang ${ }^{4}$, Shijing Sun ${ }^{5, *}$, Kenji Umemura ${ }^{4, *}$ \\ and Qiang Yong ${ }^{3, *}$ \\ 1 Co-Innovation Center of Efficient Processing and Utilization of Forest Resources, \\ Nanjing Forestry University, Nanjing 210037, China \\ 2 College of Furnishings and Industrial Design, Nanjing Forestry University, Nanjing 210037, China; \\ Myf1203@163.com (Y.M.); Yangziqian@njfu.edu.cn (Z.Y.); Myhuae@163.com (H.W.); \\ Sangruijuan@njfu.edu.cn (R.S.); Tracy_528@126.com (Y.F.); Wzh550@sina.com (Z.W.) \\ 3 College of Chemical Engineering, Nanjing Forestry University, Nanjing 210037, China; Szxapy@163.com \\ 4 Laboratory of Sustainable Materials, Research Institute for Sustainable Humanosphere, Kyoto Univeersity, \\ Gokasho, Uji, Kyoto 611-0011, Japan; Zhang888@rish.kyoto-u.ac.jp \\ 5 College of Material Science and Engineering, Nanjing Forestry University, Nanjing 210037, China \\ * Correspondence: Zhaozy930@126.com (Z.Z.); Sunsj-611@163.com (S.S.); Umemura@rish.kyoto-u.ac.jp (K.U.); \\ Swhx@njfu.com.cn (Q.Y.); Tel.: +86-025-8542-7793 (Z.Z.); +86-025-8542-7564 (S.S.); +81-0774-38-3652 (K.U.); \\ +86-025-8542-7471 (Q.Y.)
}

Received: 12 May 2018; Accepted: 8 June 2018; Published: 11 June 2018

check for updates

\begin{abstract}
The development of biomaterials-based adhesives is one of the main research directions for the wood-based material industry. In previous research, tannin and sucrose were used as adhesive to manufacture particleboard. However, the reaction conditions need to be optimized. In this study, sulfuric acid was added to the tannin-sucrose adhesive as a catalyst to improve the curing process. Thermal analysis, insoluble mass proportion, FT-IR, and solid state ${ }^{13} \mathrm{C}$ NMR were used to investigate the effects of sulfuric acid on the curing behavior of tannin and sucrose. Thermal analysis showed weight loss and endotherm temperature reduced from 205 and 215 to 136 and $138{ }^{\circ} \mathrm{C}$, respectively, by adding sulfuric acid. In case of the adhesive with $\mathrm{pH}=1.0$, the insoluble mass proportion achieved $81 \%$ at $160{ }^{\circ} \mathrm{C}$, which was higher than the reference at $220^{\circ} \mathrm{C}$. FT-IR analysis of the uncured adhesives showed that adding sulfuric acid leads to hydrolysis of sucrose; then, glucose and fructose converted to 5-hydroxymehthylfurfural (HMF) and levulinic acid. Dimethylene ether bridges were observed by FT-IR analysis of the cured adhesives. The results of solid state ${ }^{13} \mathrm{C}$ NMR spectrum indicated that 5-HMF participated in the curing process and formed methylene bridges with the $\mathrm{C} 8$ position of the resorcinol A-rings of tannin, whereas dimethylene ether bridges were detected as a major chemical chain of the polymer. Lab particleboards were produced using $20 \mathrm{wt} \%$ resin content at $180^{\circ} \mathrm{C}$ and $10 \mathrm{~min}$ press time; the tannin-sucrose adhesive modified with sulfuric acid to $\mathrm{pH}=1.0$ exhibited better performance than the unmodified tannin-sucrose adhesive; the properties of the boards fulfilled the requirement of Japanese Industrial Standard (JIS) A5908 type 15.
\end{abstract}

Keywords: natural adhesive; tannin; sucrose; sulfuric acid catalyst; curing behavior; particleboard

\section{Introduction}

Wood-based materials, such as particleboard, plywood, or fiberboard, are generally used in housing construction, interior decoration, and furniture manufacturing, which are frequently present in living environments [1,2]. Generally, these materials are manufactured by bonding the wooden elements with synthetic resins such as formaldehyde-based, isocyanate-based, polyvinyl acetate 
adhesives, and so on [3-5]. However, as a result of concerns about formaldehyde emissions and dependency on fossil resources, it is necessary to develop adhesives based on renewable resources, such as lignin, soybean, starch, or tannin [6-9]. However, because of the generally weak bonding performance of biomass resources, most of the studies focus on replacing only a certain part of the chemical substances derived from fossil resources with these bio-materials, which does not solve the issues fundamentally. Therefore, a significant research direction on natural adhesive aims to utilize renewable resources as only raw materials when synthesizing high-performance adhesive [10-12].

Condensed tannins comprise $90 \%$ of the total world production of commercial tannins (200,000 tons per year) [13]. Tannins are widely distributed in nature, especially in the wood and bark of various trees, such as Acacia (wattle or mimosa bark extract), Schinopsis (quebracho wood extract), Tsuga (hemlock bark extract), and Rhus (sumach extract) [9]. Condensed tannins contain high amounts of polyphenols, which commonly are utilized to produce leather $[14,15]$. The monomer of wattle tannin contains resorcinol A-rings and catechol or pyrogallol B-rings, and the free C6 or C8 sites on the A-ring react with active substances because of their strong nucleophilicity [16]. An example of such an active substance is sucrose, which is a common disaccharide, and 5-hydroxymehthylfurfural (5-HMF) generates by heat treatment $[17,18]$.

Considering the characteristics of chemical properties, tannin and sucrose were chosen as adhesive components for the work reported here. In a previous work, lab particleboards with $9 \mathrm{~mm}$ thickness were produced at a hot pressing temperature of $220^{\circ} \mathrm{C}$ and hot pressing time of $10 \mathrm{~min}$; the mechanical properties and water resistance of the board fulfilled the requirements of Japanese Industrial Standard (JIS) A 5908 type 18 standard (2003) [19,20]. However, the reaction conditions needed for the reaction between tannin and sucrose had been very harsh; therefore, it was requisite to develop a method that can reduce the curing temperature or time.

Judging from the results of the curing mechanism and thermal analysis of tannin-sucrose adhesives, 5-HMF is generated at $200{ }^{\circ} \mathrm{C}$ and then chemically reacts with tannin. The insoluble mass proportion was $0 \%$ when the temperature was lower than $200{ }^{\circ} \mathrm{C}$, indicating there was not any reaction happening between tannin and sucrose [20]. Hence, the high curing temperature between tannin and sucrose is a result of the generation temperature of 5-HMF. Based on some studies, inorganic acids could be used as catalyst to gain 5-HMF from sucrose already at a lower temperature [21-23]; this also could cause hydrolysis of tannin [24], which possibly also will accelerate the curing reaction rate. In this study, sulfuric acid was used as a catalyst to reduce the reaction temperature between tannin and sucrose: the effects of the sulfuric acid addition on the curing temperature, the curing behavior, and the bonding performance were investigated.

\section{Materials and Methods}

\subsection{Materials}

Wattle tannin (commercial name: tannic acid ME) was purchased from the Fuji Chemical Industry Co. (Wakayama, Japan). Sucrose (guaranteed reagent) and sulfuric acid were purchased from Nacalai Tesque, Inc. (Kyoto, Japan) and Wako pure chemical industries Ltd. (Kyoto, Japan), respectively. Tannin and sucrose were used without further purification, but were dried in a vacuum oven at $60^{\circ} \mathrm{C}$ for $15 \mathrm{~h}$. The wood particles were screened by a sieving machine to collect particle sizes in the range of 0.9 to $5.9 \mathrm{~mm}$. Before particleboard manufacturing, the particles (original moisture content $3-4 \mathrm{wt} \%$ ) were dried in an oven at $80^{\circ} \mathrm{C}$ for $12 \mathrm{~h}$ to a final moisture content of $2 \mathrm{wt} \%$.

\section{2. $p H$ Value Adjustment of Adhesive Solution by Adding Sulfuric Acid}

The sulfuric acid content in the tannin-sucrose mixture was determined by the adjustment of $\mathrm{pH}$ values. The optimal ratio of tannin to sucrose is $25: 75$ [19]. In this study, $25 \mathrm{~g}$ tannin and $75 \mathrm{~g}$ sucrose were mixed in a beaker, and $150 \mathrm{~g}$ distilled water was added to the mixture to get a tannin-sucrose adhesive solution at $40 \mathrm{wt} \%$ concentration. Pure sulfuric acid was also mixed with distilled water 
to $40 \mathrm{wt} \%$ concentration. Subsequently, $0.1 \mathrm{~g}$ of the sulfuric acid solution was added stepwise to the tannin-sucrose solution. The viscosity and $\mathrm{pH}$ of the solution at $20^{\circ} \mathrm{C}$ was measured by atational viscometer (Viscolead One, Fungilab S.A., Barcelona, Spain) and a pH meter (D-51, Horiba Scientific, Kyoto, Japan), respectively. This process was repeated several times until the tannin-sucrose solution reached $\mathrm{pH}$ 1.0. Basic information regarding the tannin-sucrose-sulfuric acid mixture is presented in Table 1.

Table 1. Viscosity and $\mathrm{pH}$ of the tannin-sucrose-sulfuric acid solution.

\begin{tabular}{ccccc}
\hline $\begin{array}{c}\text { Addition of Sulfuric } \\
\text { Acid Solution (g) }\end{array}$ & $\begin{array}{c}\text { Mixture Ratio of } \\
\text { Tannin-Sucrose-Sulfuric Acid }\end{array}$ & Concentration (wt \%) & Viscosity at $2 \mathbf{0}^{\circ} \mathbf{C}(\mathbf{m P a} \cdot \mathbf{s})$ & $\mathbf{p H}$ \\
\hline 0 & $25: 75: 0$ & & 51.3 & 4.8 \\
0.9 & $25: 75: 0.36$ & & 51.0 & 2.5 \\
1.25 & $25: 75: 0.50$ & 40 & 50.4 & 2.0 \\
2.4 & $25: 75: 0.96$ & & 49.5 & 1.5 \\
10.4 & $25: 75: 4.16$ & 47.3 & 1.0 \\
\hline
\end{tabular}

\subsection{Thermal Analysis}

After the various $\mathrm{pH}$ adjustments, $100 \mathrm{~g}$ of each variation in sulfuric acid content was poured into glass vials and then freeze-dried. The dried mixtures were pulverized to smaller than $250-\mu \mathrm{m}$ mesh size to obtain the uncured adhesive powder. Thermogravimetric analysis (TGA) and differential scanning calorimetry (DSC) were carried out using a TGA 2050 (TA Instruments, Tokyo, Japan) and DSC 2910 (TA Instruments, Tokyo, Japan), respectively, and the samples were scanned from room temperature to $400{ }^{\circ} \mathrm{C}$ at a rate of $10{ }^{\circ} \mathrm{C} /$ min under nitrogen purging with the flow rate at 100 and $40 \mathrm{~mL} / \mathrm{min}$, respectively.

\subsection{Measurement of Insoluble Mass Proportion}

Samples of the uncured adhesive powders were separately heated up to $160,180,200$, and $220^{\circ} \mathrm{C}$, respectively, for $10 \mathrm{~min}$ to achieve curing. Then, $2 \mathrm{~g}$ samples of each cured adhesive sample were boiled in distilled water for $4 \mathrm{~h}$ to obtain the wet insoluble residue. The boiling treatment was carried out in triplicate. All samples obtained from heating treatments, as well as the residues after the boiling treatment, were vacuum-dried at $60^{\circ} \mathrm{C}$ for $15 \mathrm{~h}$. The insoluble mass proportion was calculated by the following equation:

$$
\text { Insoluble mass proportion }(\%)=\frac{\text { Weight }(\text { dried insoluble mass })}{\text { Weight }(\text { cured adhesive })} \times 100 \%
$$

\subsection{Fourier Transform Infrared Spectra (FTIR)}

The chemical changes between uncured and cured adhesives were investigated by FTIR spectra using spectrophotometer FT/IR-4200 (JASCO Corporation, Easton, MD, USA), with KBr disk method and recording with an average of 32 scans at a resolution of $4 \mathrm{~cm}^{-1}$. The two adhesives, (i) adjusted to $\mathrm{pH}=1.0$ and heated at $160{ }^{\circ} \mathrm{C}$ for $10 \mathrm{~min}$ and (ii) at original $\mathrm{pH}=4.8$ heated at $220^{\circ} \mathrm{C}$ for $10 \mathrm{~min}$, gave the same insoluble mass proportion; both kinds of the insoluble mass were also investigated by FT-IR for the effects of sulfuric acid on the reaction mechanism.

\section{6. ${ }^{13} \mathrm{C}$ Cross Polarization-Magic Angle Spinning (CP-MAS) NMR}

${ }^{13} \mathrm{C} C \mathrm{CP}-\mathrm{MAS}$ NMR spectra were acquired at room temperature on a Varian $400 \mathrm{NMR}$ system spectrometer with a Varian $5 \mathrm{~mm} \mathrm{CP-MAS}$ and a multipulse probe. Powder samples were placed in $\mathrm{Si}_{3} \mathrm{~N}_{4}$ rotors $5 \mathrm{~mm}$ in diameter with an o-ring cap, and then spun at the magic angle at the frequency of 8-9 kHz. ${ }^{13} \mathrm{C}$ NMR spectra were taken at $100.56 \mathrm{MHz}$ with a $40 \mathrm{~ms}$ acquisition period, $30.5 \mathrm{kHz}$ spectral width, and a frequency of $86 \mathrm{kHz}$. The pulse sequence was continuous ${ }^{1} \mathrm{H}$ decoupling with a small phase incremental alteration (SPINAL). Cross-polarization involved $2.0 \mathrm{~ms}$ contact time. The ${ }^{13} \mathrm{C}$ 
CP-MAS NMR spectra were obtained using the regular CP-MAS sequence at a $500 \mu$ s contact time with a $4.0 \mu$ s long $\pi / 2$ pulse and a $5.0 \mathrm{~s}$ of recycle delay.

\subsection{Manufacture of Particleboard}

The two adhesives at $\mathrm{pH}=4.8$ and 1.0 with $40 \mathrm{wt} \%$ concentration were sprayed onto wood particles in a blender at $20 \mathrm{wt} \%$ resin content based on the weight of the oven-dried particles, and the sprayed particles were again dried at $80{ }^{\circ} \mathrm{C}$ for $12 \mathrm{~h}$ until the moisture content was $4-7 \mathrm{wt} \%$. The dried particles were mat-formed using a forming box of $300 \mathrm{~mm} \times 300 \mathrm{~mm}$. Then, the mat was hot-pressed at $180{ }^{\circ} \mathrm{C}$ for $10 \mathrm{~min}$ with distance bars of $9 \mathrm{~mm}$ to control the thickness. The target density of the boards was $800 \mathrm{~kg} / \mathrm{m}^{3}$. Considering the given bonding properties of natural substances, the resin content and the hot pressing time were adjusted in this stage of the work still to significantly higher values than usually given for synthetic resins in the wood industry.

\subsection{Evaluation of Particleboard Properties}

The particleboards were conditioned for 1 week at $20^{\circ} \mathrm{C}$ and $60 \%$ relative humidity (RH), and then evaluated according to the Japanese Industrial Standard for particleboard (JIS A 5908, 2003). The static three-point bending test was carried out on a $200 \mathrm{~mm} \times 30 \mathrm{~mm} \times 9 \mathrm{~mm}$ specimen from each board, and the effective span and loading speed were $150 \mathrm{~mm}$ and $10 \mathrm{~mm} / \mathrm{min}$, respectively. The modulus of rupture (MOR) was calculated from the bending test. The internal bond strength (IB) test was performed on a $50 \mathrm{~mm} \times 50 \mathrm{~mm}$ specimen with a loading speed of $2 \mathrm{~mm} / \mathrm{min}$, and thickness swelling (TS) after water immersion for $24 \mathrm{~h}$ at $20^{\circ} \mathrm{C}$ was measured in specimens of the same size. Each experiment was performed five times, and the average values and standard deviations were calculated. Statistical significance was considered for $p$-values $<0.5$.

\section{Results and Discussion}

\subsection{Thermal Analysis}

Figure 1 shows the thermogravimetric (TG) and derivative TG (DTG) curves of the various mixtures at the different $\mathrm{pH}$ adjustments. Tannin and sucrose, both separately adjusted with sulfuric acid to $\mathrm{pH}=1.0$ were used as control. The acidified tannin exhibited a linear profile, indicating a continuous degradation during heating. Contrary to this, the acidified sucrose showed a two-step degradation in the DTG curve with two peaks at 138 and $155^{\circ} \mathrm{C}$; these mass losses seem to be attributed to the pyrolysis or caramelization of sucrose in acidic conditions [25]. The DTG curve of the unmodified tannin/sucrose mixture ( $\mathrm{pH} 4.8$ ) shows a sharp peak at around $205^{\circ} \mathrm{C}$, which was considered as the thermolysis of sucrose, generation of 5-HMF, and reaction with tannin [20]. The addition of sulfuric acid to the tannin-sucrose mixes reduces the temperature of mass loss, as seen from both curves, TG and DTG. The version with $\mathrm{pH}=1.0$ exhibits a two-step degradation; the first stage occurs at 50 to $115^{\circ} \mathrm{C}$, based on the DTG curve of acidified tannin, this was possible because of the degradation of tannin. The second peak was observed at around $153^{\circ} \mathrm{C}$, which seems to be caused by the pyrolysis or caramelization of sucrose [26,27]. Moreover, additional peaks in the range 254 to $274{ }^{\circ} \mathrm{C}$ were observed for the samples with $\mathrm{pH}$ even higher; with decreasing $\mathrm{pH}$ values, the height of these peaks became less and finally the peak disappeared in the $\mathrm{pH}=1.0$ adhesive. Judging from the DTG profile of sucrose in the previous research, this was possible because of the production of a black aerated char-like solid [20]; the addition of bigger amounts of sulfuric acid obviously changed the reaction equilibrium leading to excess sucrose formation in the reaction system. 


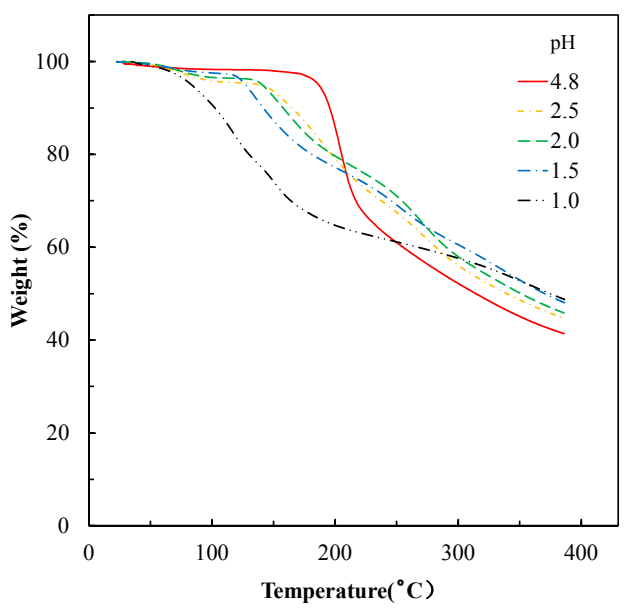

(a)

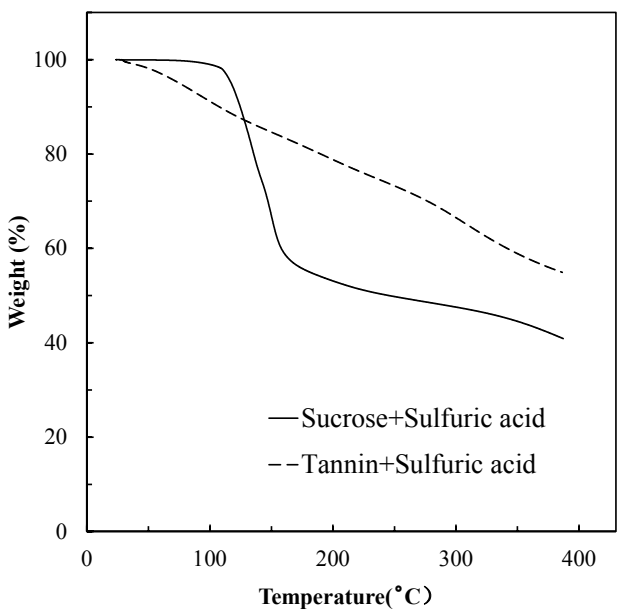

(c)

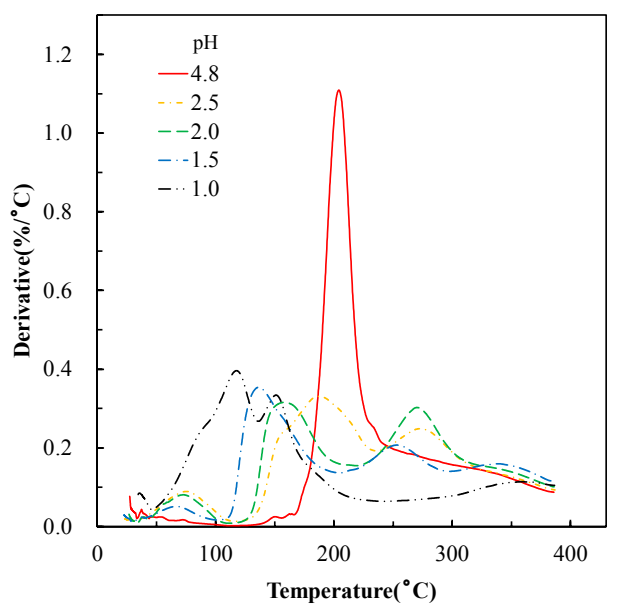

(b)

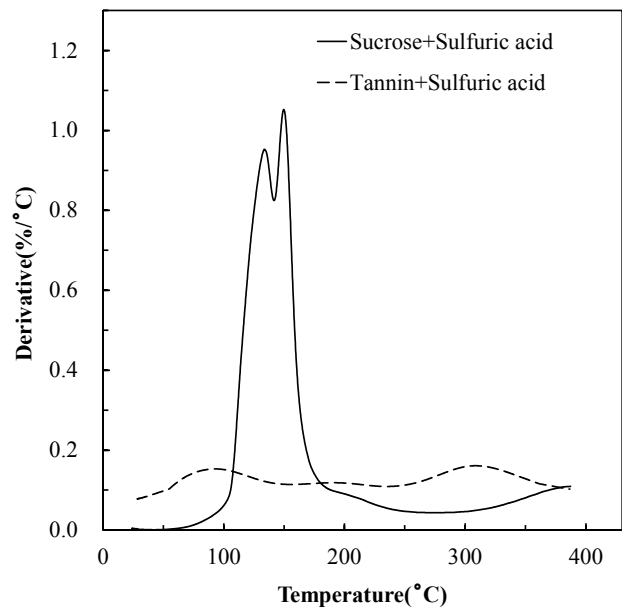

(d)

Figure 1. Thermogravimetric (TG) and derivative TG (DTG) curves of mixtures. (a) TG curves of tannin-sucrose-sulfuric acid mixture with different $\mathrm{pH}$; (b) DTG curves of tannin-sucrose-sulfuric acid mixture with different $\mathrm{pH}$; (c) TG curves of tannin-sulfuric acid and sucrose-sulfuric acid mixture at $\mathrm{pH}=1.0 ;(\mathbf{d})$ DTG curves of tannin-sulfuric acid and sucrose-sulfuric acid mixture at $\mathrm{pH}=1.0$.

Figure 2 shows DSC curves of the adhesives. The mixture of sucrose and sulfuric acid has a sharp endothermic peak at $118{ }^{\circ} \mathrm{C}$, indicating melting and caramelization already at lower temperatures [20]. The acidified tannin exhibits only a weak endotherm peak at around $115{ }^{\circ} \mathrm{C}$, attributed to the degradation of tannin [24]. The tannin-sucrose mix at $\mathrm{pH}=4.8$, without addition of sulfuric acid, gives two endothermic peaks at 180 and $215^{\circ} \mathrm{C}$, which were attributed to the melting of sucrose and the curing reaction, respectively [20]. The addition of sulfuric acid to the tannin-sucrose mix merges the two endotherm peaks to one peak and moves this to lower temperatures. At $\mathrm{pH}=1.0$ and 1.5, a shoulder appeared at around $115^{\circ} \mathrm{C}$, which is possible because of the decomposition of tannin or the melting of sucrose. In addition, a sharp peak located at $128^{\circ} \mathrm{C}$ was attributed to the caramelization of sucrose or the reaction between 5-HMF and tannin [26,27]. Judging from the results of thermal analysis, the addition of sulfuric acid significantly reduced the reaction temperature between tannin and 5-HMF, which was produced from heating of sucrose. 


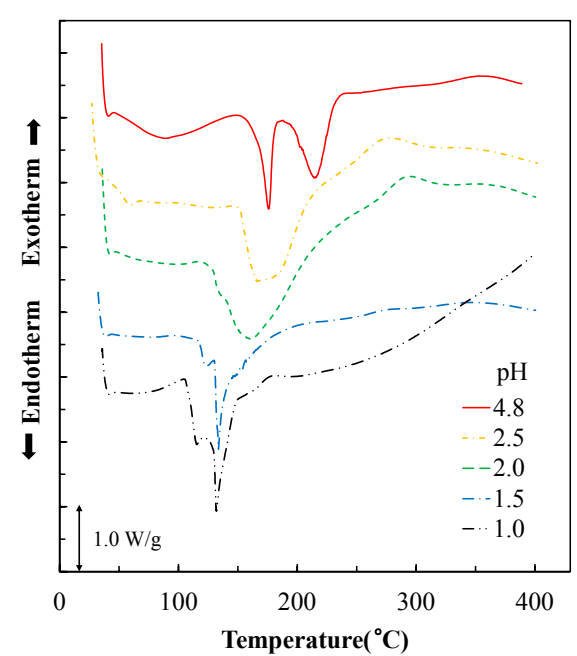

(a)

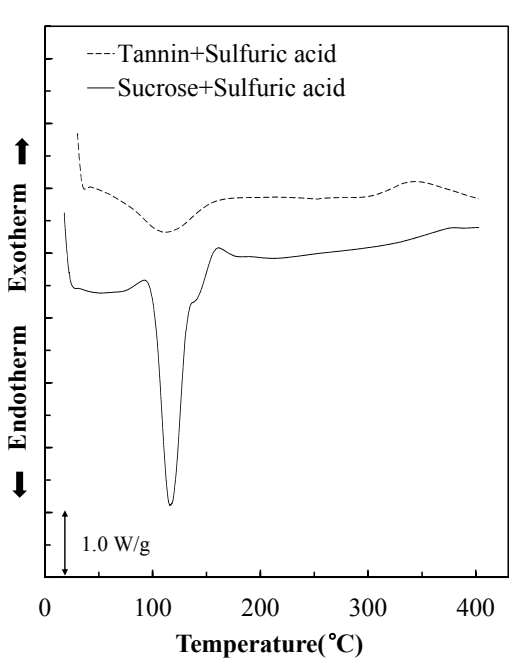

(b)

Figure 2. Differential scanning calorimetry (DSC) curves of the mixtures. (a) TG curves of tannin-sucrose-sulfuric acid mixture with different $\mathrm{pH}$; (b) TG curves of tannin-sulfuric acid and sucrose-sulfuric acid mixture at $\mathrm{pH}=1.0$.

\subsection{Insoluble Mass Proportion}

The increase of insoluble mass proportion of the various adhesives when heating to different temperatures is shown in Figure 3. The adhesives adjusted to different $\mathrm{pH}$ values were heated at $160,180,200$, and $220{ }^{\circ} \mathrm{C}$ for $10 \mathrm{~min}$, and then the partly cured adhesives were boiled for $4 \mathrm{~h}$ before determining the insoluble mass proportion. Variance analysis (ANOVA) showed no significant $(p>0.05)$ difference between the adhesives with 4.8 and $2.5 \mathrm{pH}$ in all heating temperature conditions. The higher the temperatures, the higher was the achieved insoluble mass proportion of all mixes. The unmodified tannin-sucrose mixture, which adjusted to $\mathrm{pH}=2.5$, showed no development of insoluble material at the two lower temperatures of 160 and $180^{\circ} \mathrm{C}$. This could be verified by the results of thermal analysis showing that the mass loss and endothermic reaction peaks of these mixtures were located at around $190-200{ }^{\circ} \mathrm{C}$; at decreasing $\mathrm{pH}$ values, the insoluble mass proportion increased for each temperature level. The highest insoluble mass proportion was obtained from the adhesive at $\mathrm{pH}=1.0$; at $160{ }^{\circ} \mathrm{C}$, the ratio was already $81 \%$; this was higher than most other adhesives treated at $220^{\circ} \mathrm{C}$ and indicates the strong curing reaction between tannin and 5-HMF (created by sucrose). This reflects the fact that the addition of sulfuric acid could reduce the curing temperature of the acidified tannin-sucrose mixes.

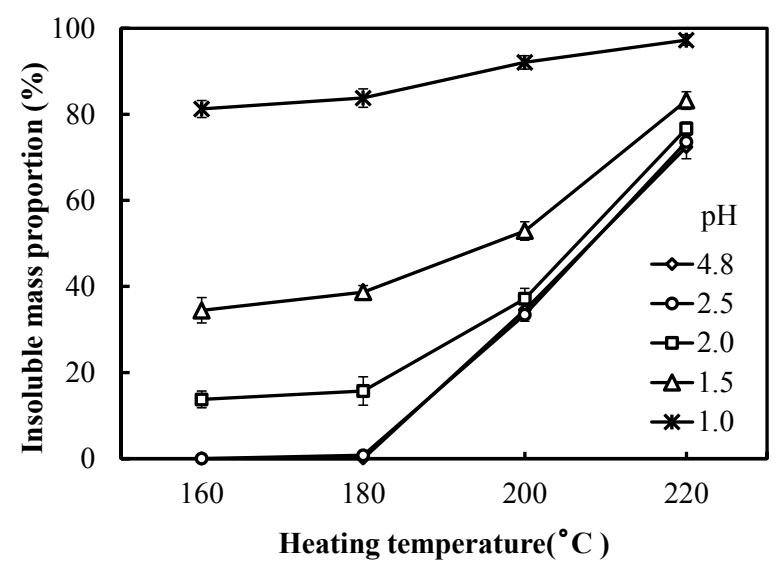

Figure 3. Insoluble mass proportion of the adhesives with different $\mathrm{pH}$ values and heated for $10 \mathrm{~min}$. 


\subsection{FT-IR Spectroscopic Analysis}

The FT-IR curves of the various uncured acidified tannin-sucrose adhesives (Figure 4) show two absorption peaks (1130 and $920 \mathrm{~cm}^{-1}$ ), disappearing when the $\mathrm{pH}$ is reduced. The peak at $1130 \mathrm{~cm}^{-1}$ was assigned to glycosidic linkage $(\mathrm{C}-\mathrm{O}-\mathrm{C})$ of sucrose $[28,29]$, and the absorption band at around $920 \mathrm{~cm}^{-1}$ was attributed to the pyranose ring of sucrose [30]. This indicates that hydrolysis happened by adding sulfuric acid into the sucrose solution. In addition, the absorption bands at 1625, 1509, and $780 \mathrm{~cm}^{-1}$ increased clearly at increasing addition of sulfuric acid. The peak located at $1625 \mathrm{~cm}^{-1}$ typically derives from aromatic $\mathrm{C}=\mathrm{C}$ stretching, possibly attributed to the dehydration of sucrose or levulinic acid [31]. The absorption band at 1509 and $780 \mathrm{~cm}^{-1}$ was a result of the characteristic of $C=C$ stretching vibration and unsubstituted $\mathrm{CH}=\mathrm{CH}$ of $5-\mathrm{HMF}$, respectively $[32,33]$. The results of these spectra changes of uncured adhesives indicate that the addition of sulfuric lead to the hydrolysis of sucrose, and then, glucose and fructose converted to 5-HMF and levulinic acid.

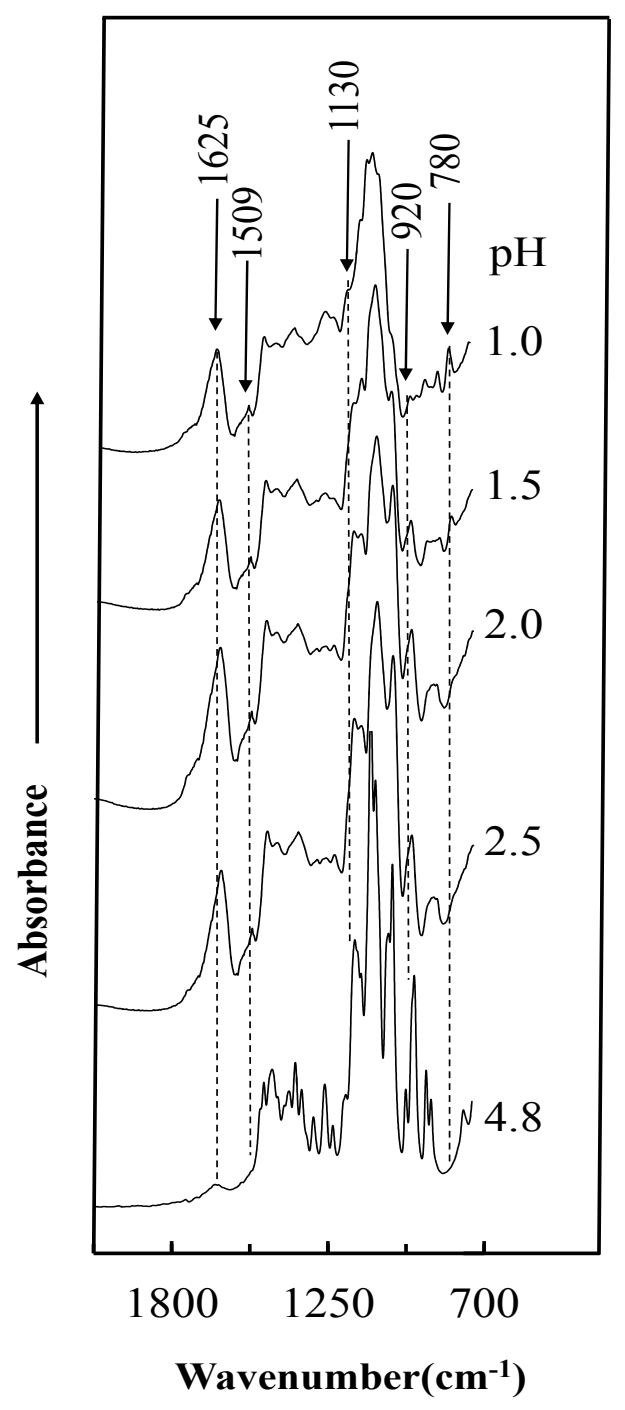

Figure 4. FT-IR spectra of uncured adhesives.

Figure 5 shows the FT-IR profiles of the insoluble mass of the acidified tannin-sucrose adhesive with $\mathrm{pH}=1.0$ cured at $160^{\circ} \mathrm{C}$ for $10 \mathrm{~min}$ and the unmodified tannin-sucrose adhesive with $\mathrm{pH}=4.8$ cured at $220^{\circ} \mathrm{C}$ for $10 \mathrm{~min}$. Two peaks increased as $\mathrm{pH}$ was reduced: (i) the band at $1705 \mathrm{~cm}^{-1}$, attributed to $\mathrm{C}=\mathrm{O}$ stretching of the carbonyl group [34]; and (ii) the band at $1200 \mathrm{~cm}^{-1}$, associated with 
the $-\mathrm{C}-\mathrm{O}$ stretching of the benzene nucleus and / or dimethylene ether bridges $\left(-\mathrm{CH}_{2}-\mathrm{O}-\mathrm{CH}_{2}-\right)$ [16] . The increasing of dimethylene ether bridges indicated that the sulfuric acid promotes the curing between tannin and 5-HMF, which was created by the heating of sucrose.

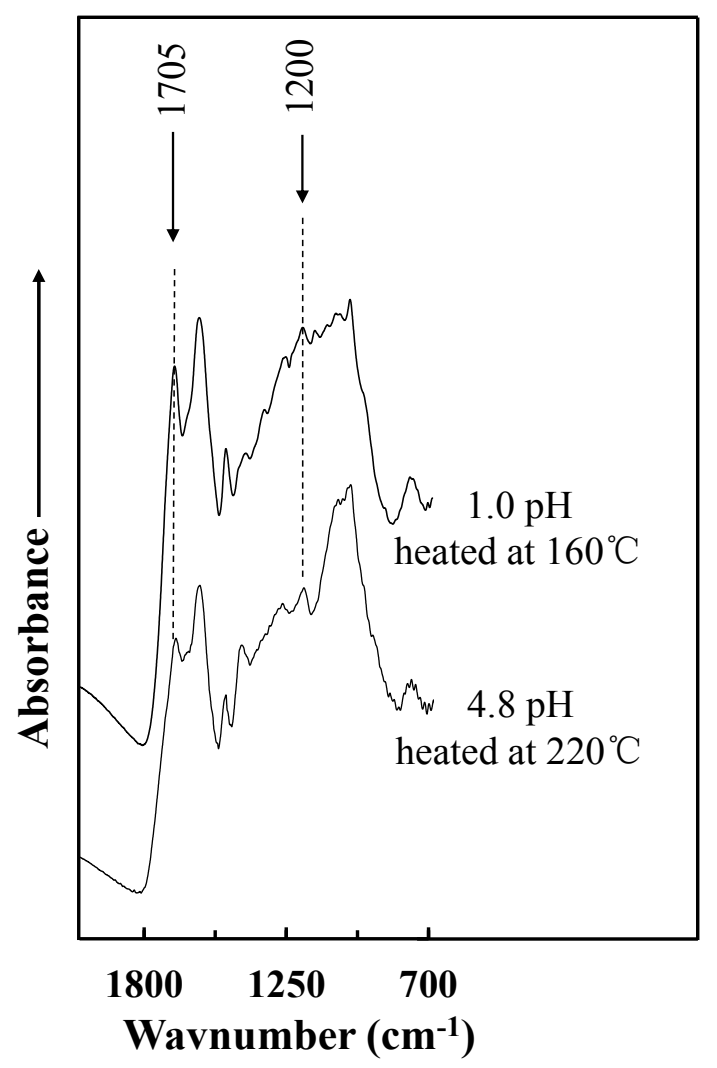

Figure 5. FT-IR spectra of insoluble matter obtained from cured adhesives.

\section{4. ${ }^{13} \mathrm{C} C P-M A S$ NMR Analysis}

In Figure 6, the solid state ${ }^{13} \mathrm{C}$ NMR spectra of (i) the insoluble matter obtained from the tannin-sucrose-sulfuric acid adhesive with $\mathrm{pH}=1.0 \mathrm{pH}$ cured at $160{ }^{\circ} \mathrm{C}$ for $10 \mathrm{~min}$; and (ii) the unmodified tannin-sucrose adhesive with $\mathrm{pH}=4.8$ and cured at $220^{\circ} \mathrm{C}$ for $10 \mathrm{~min}$, are compared. The spectra look very similar, which means that the addition of sulfuric acid changed the rate of the curing reaction, but not the reaction mechanisms between tannin and sucrose-5-HMF. The peak at $110 \mathrm{ppm}$ was attributed to the $\mathrm{C} 2$ and $\mathrm{C} 3$ of the furanic ring of 5-HMF, while the other two signals at 144 and $156 \mathrm{ppm}$, which overlap with the aromatic $\mathrm{C}-\mathrm{O}$ of the tannin, certified that 5-HMF participated in the curing reaction [35]. In addition, the peak at around $110 \mathrm{ppm}$ was also attributed to the C8 position of tannin for methylene ether bridging [36,37]. A small peak at $175 \mathrm{ppm}$ was derived from the carbonyl group, and this peak was possible as a result of the unreacted aldehyde group of 5-HMF [38]. A major peak at around $72 \mathrm{ppm}$ was very intense in both adhesives, which was attributed to the dimethylene ether bridges $\left(-\mathrm{CH}_{2}-\mathrm{O}-\mathrm{CH}_{2}-\right)$ between two 5-HMF molecules $[38,39]$. The absorption at $30 \mathrm{ppm}$ from the insoluble mass of tannin-sucrose-sulfuric acid adhesive was a result of methylene bridges $\left(-\mathrm{CH}_{2}-\right)$, which were formed by the reaction of 5-HMF with tannin [40]. The results of ${ }^{13} \mathrm{C}$ NMR spectrum show that 5-HMF participated in the curing reaction and forms methylene bridges with $\mathrm{C} 8$ of the resorcinol A-rings of tannin. Furthermore, dimethylene ether bridges were detected as a major chemical structure of the cured tannin-sucrose mixture. The sulfuric acid played a catalytic role and accelerated the generation of 5-HMF already at lower temperatures, and thus reduces the necessary curing temperature between tannin and sucrose. Based on the chemical information gained from FT-IR 
and solid state ${ }^{13} \mathrm{C}$ NMR, a scheme of the curing process of tannin-sucrose-sulfuric acid is shown in Figure 7.

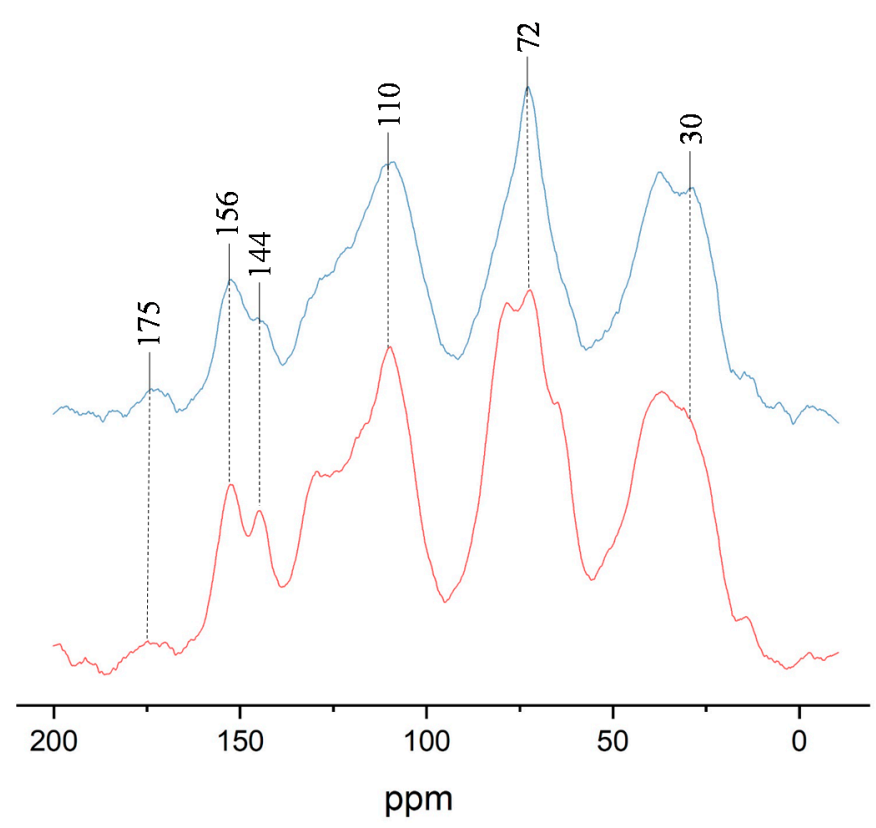

Figure 6. Solid state ${ }^{13} \mathrm{C}$ NMR spectrum of the insoluble matter of tannin-sucrose-sulfuric acid adhesive with $1.0 \mathrm{pH}$ cured at $160{ }^{\circ} \mathrm{C}$ for $10 \mathrm{~min}$ (blue) and tannin-sucrose adhesive cured at $220^{\circ} \mathrm{C}$ for $10 \mathrm{~min}$ (red).

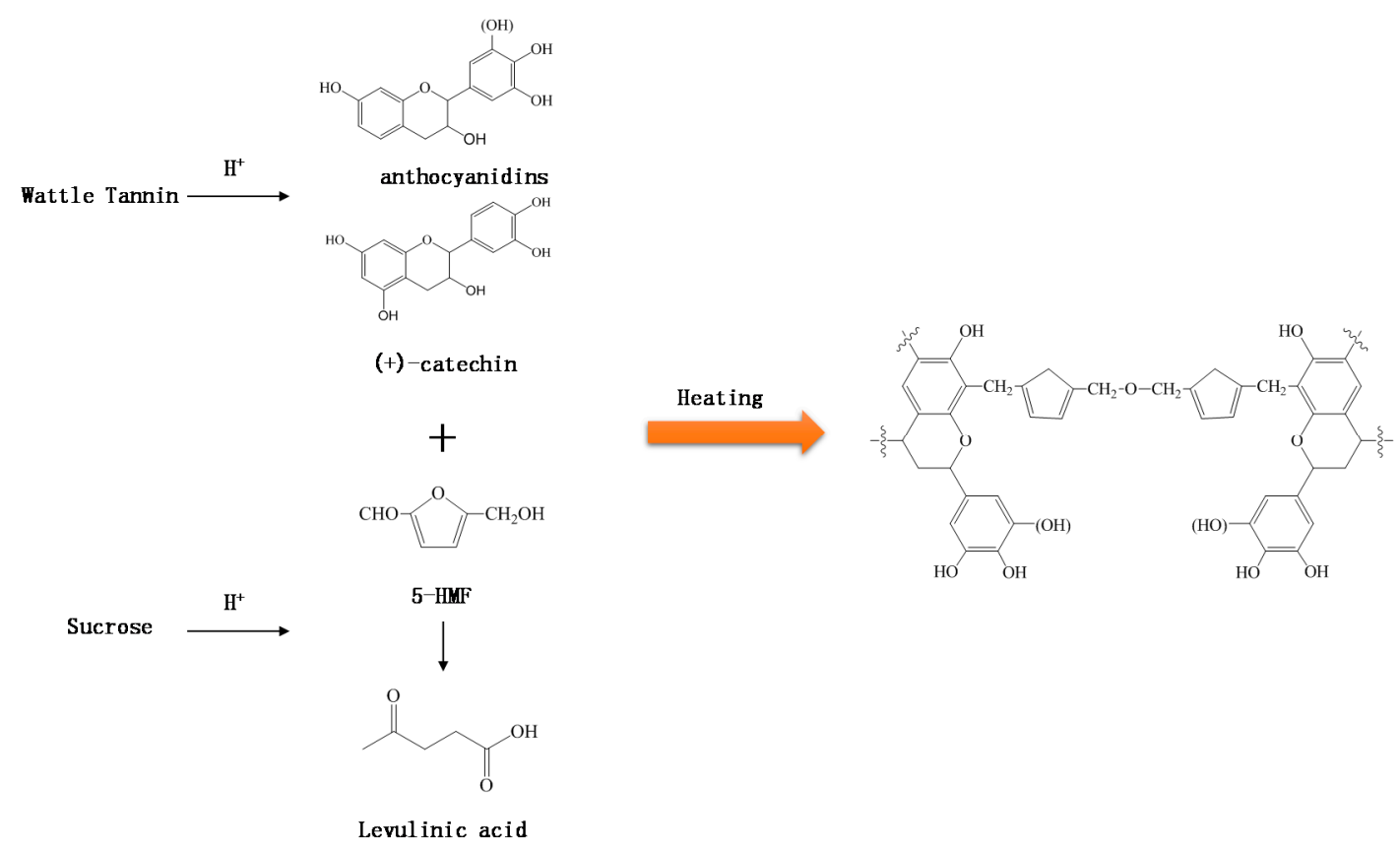

Figure 7. Possible reaction process between wattle tannin and sucrose by adding sulfuric acid.

\subsection{Bending, Internal Bond Strength, and Thickness Swelling of Particleboard}

Figure 8 shows the mechanical properties (MOR and IB) and the thickness swelling (TS) of lab particleboards with the unmodified tannin-sucrose adhesive $(\mathrm{pH}=4.0)$ and the acidified version $(\mathrm{pH}=1.0)$. MOR, IB, and TS based on the acidified adhesive were improved when compared with the 
unmodified adhesive; the samples for TS based on the $\mathrm{pH}=4.8$ version were even destroyed during the water immersion. This indicates that the addition of sulfuric acid improved all properties of the lab boards significantly. The properties of the particleboard bonded by $1.0 \mathrm{pH}$ adhesive fulfill the requirements type 15 of JIS A5908, however, it must be considered that the preparation conditions of the lab boards are still far away from usual industrial conditions. In a previous study, lab particleboards were prepared using the non-modified tannin-sucrose mixture $(\mathrm{pH}=4.8)$ as adhesive at even higher resin content and press temperatures; the boards showed better mechanical properties (MOR 21.4 MPa, IB 1.45 MPa) at more or less the same TS $(9.6 \%)$ when compared with the acidified version at lower resin content and lower press temperatures. Because of the fact that several parameters are different in this comparison, a clear statement is not possible; however, it can nevertheless be concluded that the sulfuric acid promoted the curing process between tannin and sucrose (via 5-HMF). The low $\mathrm{pH}$ of the adhesive mixture may not only induce acidic catalysis of the formation of 5-HMF out of sucrose, but may also lead to a certain decomposition of cellulose and hemicellulose, especially at higher temperatures and long press times [41].
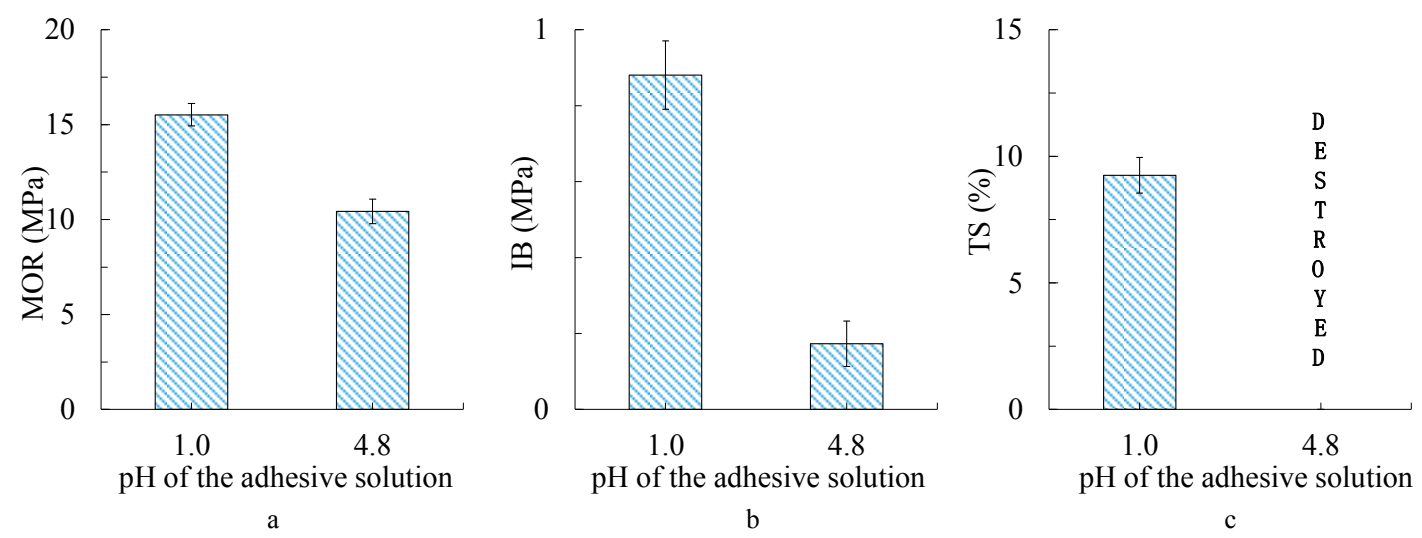

Figure 8. Mechanical properties and water resistance of the particleboards bonded by the tannin-sucrose-sulfuric acid adhesive ( $\mathrm{pH}$ 1.0) and the tannin-sucrose adhesive ( $\mathrm{pH} 4.8)$ at $180{ }^{\circ} \mathrm{C}$ for 10 min. (a) Bending properties; (b) internal bond (IB) strength properties; and (c) thickness swelling (TS) properties. MOR-modulus of rupture.

\section{Conclusions}

Sulfuric acid was added to tannin-sucrose mixtures as a catalyst to accelerate the reaction rate of the curing process and to reduce the curing temperature. Thermal analysis shows that, in this reaction, the rate of weight loss increases and temperature decreases the lower the $\mathrm{pH}$ of the adhesive solution. Both TG/DTG and DSC showed that at $\mathrm{pH}=1.0 \mathrm{pH}$, the decomposition of sucrose to 5-HMF occurred at much lower temperatures (136 and $128^{\circ} \mathrm{C}$, respectively) when compared with the unmodified tannin-sucrose mixture at $\mathrm{pH}=4.8\left(205\right.$ and $215^{\circ} \mathrm{C}$, respectively). Additionally, the generation of insoluble residues for the low $\mathrm{pH}$ version occurred at lower temperatures and to a further extent when compared with the unmodified version.

FT-IR of the uncured adhesives confirmed that the addition of sulfuric acid led to the hydrolysis of sucrose to glucose and fructose, and further to 5-HMF and levulinic acid. Dimethylene ether bridges and carbonyl group were detected by FT-IR analysis of the cured adhesives. Solid state ${ }^{13} \mathrm{C}$ NMR indicated that 5-HMF participates in the curing reaction and forms methylene bridges with the $\mathrm{C} 8$ of the resorcinol A-rings of tannin; further, dimethylene ether bridges were detected as a major chemical structure in the cured resin, originating from the condensation reaction between the hydroxyl groups of two 5-HMF molecules already linked to tannin.

The properties of lab particleboards using the acidified tannin-sucrose mix as adhesive improved significantly when compared with the unmodified version. In principle, the requirements for 
board type 15 of JIS A5908 were fulfilled, however, at production conditions, in terms of adhesive consumption and press time, which are still far outside industrial and even usual lab conditions. The improvement of the board properties is based on the higher rate of thermal decomposition of sucrose to 5-HMF, even at a lower temperature, when the $\mathrm{pH}$ of the tannin-sucrose mixture is adjusted to low values. Possible positive or also negative consequences of the low $\mathrm{pH}$ on potential decomposition reactions of cellulose or other wood constituents, as well as risk of corrosion, however, need further attention when introducing this type of adhesive into the industrial practice. Based on these considerations, further development work will concentrate on reducing acidity of this type of adhesive; furthermore, possible application for plywood shall be investigated.

Author Contributions: Z.Z. and S.S. contributed to synthesis, testing, data analysis, and wrote the manuscript. Y.M., Z.Y., H.W., R.S. and C.H. suggested and supervised the work and revised the manuscript. Z.W., M.Z., K.U., and Q.Y. provided constructive suggestions about this work and contributed to the characterization of adhesives.

Funding: This research was funded by Scientific Research Foundation of Nanjing Forestry University (GXL 2018009).

Acknowledgments: The authors are grateful for financial support from Scientific Research Foundation of Nanjing Forestry University (GXL2018009).

Conflicts of Interest: The authors declare no conflict of interest.

\section{References}

1. Guan, C.; Zhang, H.; Hunt, J.; Yan, H. Determining shear modulus of thin wood composite materials using a cantilever beam vibration method. Constr. Build. Mater. 2016, 121, 285-289. [CrossRef]

2. Sellers, T.J. Wood adhesive innovations and applications in north america. For. Prod. J. 2001, 51, 12-22.

3. Li, J.; Luo, J.; Li, X.; Yi, Z.; Gao, Q.; Li, J. Soybean meal-based wood adhesive enhanced by ethylene glycol diglycidyl ether and diethylenetriamine. Ind. Crops Prod. 2015, 74, 613-618. [CrossRef]

4. Cheng, H.; Ford, C.; Dowd, M.; He, Z. Soy and cottonseed protein blends as wood adhesives. Ind. Crops Prod. 2016, 85, 324-330. [CrossRef]

5. Aracri, E.; Blanco, D.; Tzanov, T. An enzymatic approach to develop a lignin-based adhesive for wool floor coverings. Green Chem. 2016, 16, 2597-2603. [CrossRef]

6. Li, R.; Gutierrez, J.; Chung, Y.; Frank, C.; Billington, S.; Sattely, E. A lignin-expoxy resin derived from biomass as an alternative to formaldehyde-based wood adhesive. Green Chem. 2018, 20, 1459-1466. [CrossRef]

7. Yuan, C.; Chen, M.; Luo, J.; Li, X.; Gao, Q.; Li, J. A novel water-based process produces eco-friendly bio-adhesive made from green cross-linked soybean soluble polysacharide and soy protein. Carbohydr. Polym. 2017, 169, 417-425. [CrossRef] [PubMed]

8. Ferdosian, F.; Pan, Z.; Gao, G.; Zhao, B. Bio-based adhesives and evaluation for wood composites application. Polymers 2017, 9, 70. [CrossRef]

9. Pizzi, A. Wood products and green chemistry. Ann. For. Sci. 2016, 73, 185-203. [CrossRef]

10. Umemura, K.; Ueda, T.; Munawar, S.; Kawai, S. Application of citric acid as natural adhesive for wood. J. Appl. Polym. Sci. 2012, 123, 1991-1996. [CrossRef]

11. Zhang, Y.; Wu, J.; Li, H.; Yuan, T.; Wang, Y.; Sun, R. Heat treatment of industrial alkaline lignin and its potential application as an adhesive for green wood-lignin composites. ACS Sustain. Chem. Eng. 2017, 5, 7269-7277. [CrossRef]

12. Kusumah, S.; Umemura, K.; Yoshioka, K.; Miyafuji, H.; Kanayama, K. Utilization of sweet sorghum bagasse and sitric acid for manufacturing of particleboard I: Effects of pre-drying treatment and citric acid content on the board properties. Ind. Crops Prod. 2016, 84, 34-42. [CrossRef]

13. Pizzi, A. Recent developments in eco-efficient bio-based adhesives for wood bon bonding: Opportunities and issues. J. Adhes. Sci. Technol. 2006, 20, 829-846. [CrossRef]

14. Khanbabaee, K.; Van, T. Tannins: Classification and definition. Nat. Prod. Rep. 2011, 18, 641-649.

15. Maier, M.; Oelbermann, A.; Renner, M.; Weidner, E. Screening of european medicinal herbs on their tannin content- new potenitial tanning agents for the leather industry. Ind. Crops Prod. 2017, 99, 19-26. [CrossRef] 
16. Kim, S.; Kim, H. Curing behavior and viscoelastic properties of pine and wattle tannin-based adhesives studied by dynamic mechanical thermal analysis and FT-IR-ATR spectroscopy. J. Adhes. Sci. Technol. 2003, 17, 1369-1383. [CrossRef]

17. Jeong, J.; Antonyraj, C.; Shin, S.; Kim, S.; Kim, B.; Lee, K.; Cho, J. Commercially attractive process for production of 5-hydroxymethyl-2-furfural from high fructose corn syrup. J. Ind. Eng. Chem. 2013, 19, 1106-1111. [CrossRef]

18. Lee, J.; Thomas, L.; Jerrell, J.; Feng, H.; Cadwallader, K.; Schmidt, S. Investigation of thermal decomopsition as the kinetic process that causes the loss of crystalline structure in sucrose using a chemical analysis approach. J. Agric. Food Chem. 2011, 59, 702-712. [CrossRef] [PubMed]

19. Zhao, Z.; Umemura, K. Investigation of a new natural particleboard adhesive composed of tannin and sucrose. J. Wood Sci. 2014, 60, 269-277. [CrossRef]

20. Zhao, Z.; Umemura, K. Investigation of a new natural particleboard adhesive composed of tannin and sucrose. 2. effect of pressing temperature and time on board properties, and characterization of adhesive. Bioresources 2015, 10, 2444-2460. [CrossRef]

21. Wigins, L. The utilization of sucrose. Adv. Carbohydr. Chem. 1949, 4, 293-336.

22. Girisuta, B.; Danon, B.; Manurung, R.; Janssen, L.; Heeres, H. Experimental and kinetic modelling studies on the acid-catalysed hydrolysis of the water hyacinth plant to levulinic acid. Bioresour. Technol. 2008, 99, 8367-8375. [CrossRef] [PubMed]

23. Tarabanko, V.; Chernyak, M.; Aralova, S.; Kuznetsov, B. Kinetisc of levulinic acid formation from carbohydrates at moderate temperatures. React. Kinet. Catal. Lett. 2002, 75, 117-126. [CrossRef]

24. Arbenz, A.; Avérous, L. Chemical modification of tannins to elaborate aromatic biobased macromolecular architectures. Green Chem. 2015, 17, 2626-2646. [CrossRef]

25. Tan-Soetedjo, J.; Bovenkamp, H.; Abdilla, R.; Rasrendra, C.; Ginkel, J.; Heeres, H. Experimental and kinetic modeling studies on the conversion of sucrose to levulinic acid and 5-HMF using sulfuric acid in water. Ind. Eng. Chem. Res. 2017, 56, 13228-13239. [CrossRef] [PubMed]

26. Dalluge, D.; Daugaard, T.; Johnston, P.; Kuzhiyil, N.; Wright, M.; Brown, R. Continuous production of sugars from pyrolysis of acid-infused lignocellulosic biomass. Green Chem. 2014, 16, 4144-4155. [CrossRef]

27. Ajandouz, E.; Puigserver, A. Nonenzymatic browning reaction of essential amino acids: Effect of $\mathrm{pH}$ on caramelization and maillard reaction kinetics. J. Agric. Food Chem. 1999, 47, 1786-1793. [CrossRef] [PubMed]

28. Chylińska, M.; Szymańska-Chargot, M.; Zdunek, A. FT-IR and FT-Raman characterization of non-cellulosic polysaccharides fractions isolated from plant cell wall. Carbohydr. Polym. 2016, 154, 48-54. [CrossRef] [PubMed]

29. Sritham, E.; Gunasekaran, S. FTIR spectroscopic evaluation of sucrose-maltodextrin-sodium citrate bioglass. Food Hydrocoll. 2017, 70, 371-382. [CrossRef]

30. Jing, L.; Zong, S.; Li, J.; Surhio, M.; Ye, M. Purification, structural features and inhibition activity on $\alpha$-glucosidase of a novel polysaccharide from Lachnum YM406. Process Biochem. 2016, 51, 1706-1713. [CrossRef]

31. Xu, G.; Chang, C.; Fang, S.; Ma, X. Cellulose reactivity in ethanol at elevate temperature and the kinetics of one-pot preparation of ethyl levulinate from cellulose. Renew. Energy 2015, 78, 583-589. [CrossRef]

32. Zhang, M.; Yang, H.; Liu, Y.; Sun, X.; Zhang, D.; Xue, D. Hydrophobic precipitation of carbonaceous spheres from fructose by a hydrothermal process. Carbon 2012, 50, 2155-2161. [CrossRef]

33. Alakhras, F.; Holze, R. In situ UV-vis-and FT-IR-spectroscopy of electrochemically synthesized furan-thiophene copolymers. Synth. Met. 2007, 157, 109-119. [CrossRef]

34. Vaz, P.; Ribeiro-Claro, P. C-H $\cdots$ O hydrogen bonds in liquid cyclohexanone revealed by the vC=O splitting and the vC-H blue shift. J. Raman Spectrosc. 2003, 34, 863-867. [CrossRef]

35. Gandini, A.; Belgacem, M. Furans in polymer chemistry. Prog. Polym. Sci. 1997, 22, 1203-1379. [CrossRef]

36. Pizzi, A.; Scharfetter, H. The chemistry and development of tannin-based adhesives for exterior plywood. J. Appl. Polym. Sci. 1978, 22, 1745-1761. [CrossRef]

37. Kiatgrajai, P.; Wellons, J.; Gollob, L.; White, J. Kinetics of polymerization of (+)-catechin with formaldehyde. J. Org. Chem. 1982, 47, 2913-2917. [CrossRef]

38. Grenier-Loustalot, M.; Larroque, S.; Grenier, P.; Bedel, D. Phenolic resins: 4. Self-condensation of methylolphenols in formaldehyde-free media. Polymer 1996, 37, 955-964. [CrossRef]

39. Rego, R.; Adriaensens, P.; Carleer, R.; Gelan, J. Fully quantitative carbon-13 NMR characterization of resol phenol-formaldehyde prepolymer resins. Polymer 2004, 45, 33-38. [CrossRef] 
40. Tondi, G. Tannin-based copolymer resins: Synthesis and characterization by solid state 13C NMR and FT-IR spectroscopy. Polymers 2017, 9, 223. [CrossRef]

41. Saeman, J. Kinetics of wood saccharification-hydrolysis of cellulose and decomposition of sugars in dilute acid at high temperature. Ind. Eng. Chem. Res. 1945, 37, 43-52. [CrossRef] 